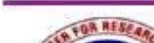 \\ APi? SPCRD GLOBAL PUBLISHING

\section{Impact of Energy Consumption on Economic Growth, Foreign Direct Investment and Environmental Degradation: Evidence from Pakistan}

\author{
a Shabana Parveen, ${ }^{b}$ Bibi Aisha Sadiqa, ${ }^{c}$ Farrah Yasmin, ${ }^{d}$ Sher Ali \\ a Assistant Professor, Department of Economics, Hazara University, Mansehra, Pakistan \\ Email: shabana_economist@yahoo.com \\ ${ }^{\mathrm{b}}$ Assistant Professor, Department of Economics, Hazara University Mansehra, Pakistan \\ Email: agrieco24@yahoo.com \\ c Assistant Professor of Economics, Govt. Emerson College Multan, Pakistan \\ Email: farraheconomist@gmail.com \\ d Assistant Professor, Department of Economics, Islamia College Peshawar, Pakistan \\ Email: drali@icp.edu.pk
}

\begin{tabular}{l}
\hline ARTICLE DETAILS \\
\hline History: \\
Accepted 22 Feb 2021 \\
Available Online March 2021 \\
Keywords: \\
Energy Use; Economic Growth; \\
Foreign Direct Investment; CO2 \\
emissions; Pakistan
\end{tabular}

JEL Classification: O13, $\mathrm{P} 28,047$

DOI: $10.47067 /$ ramss.v4i1.95

\begin{abstract}
Economic growth is a process that is not possible without a lot of energy consumption. Energy is considered as the life blood of an economy however, the energy consumption is also an important factor responsible for degrading the natural environment of the world. The present empirical work is an effort to empirically analyze the association of energy use ( $\mathrm{kg}$ of oil equivalent per capita) with economic growth (GDP per capita annual growth), foreign direct investment (FDI net inflow as percentage of GDP), and environmental degradation (CO2 emissions, metric tons per capita) in case of Pakistan. The work is based on time series data for the years 1975 to 2018. Canonical cointegrating regression (CCR) method is used for the estimation of the coefficient of the parameters. The results demonstrate that energy use has significant positive association with FDI, economic growth, and $\mathrm{CO}_{2}$ emissions. The empirical results recommend that policy makers in Pakistan require to work on policies regarding sustainable development and efficient use of energy as without achieving the efficiency in energy use, the desirable growth of the economy without environmental degradation cannot be achieved.
\end{abstract}

(C) 2021 The authors. Published by SPCRD Global Publishing. This is an open-access article under the Creative Commons Attribution-

NonCommercial 4.0

Corresponding author's email address: shabana_economist@yahoo.com

\section{Introduction}

The process of economic growth and development requires a lot of energy use/consumption in a country that is why, the importance of energy consumption for economic growth can not be 
denied. Rapu et al. (2015) argued that energy is the life blood for the growth of economies as it not only guarantees sustainable development but also increases efficiency and employment opportunities for a country. Economic growth of a country depends on energy use, among others. Furthermore, energy is the basic requirement for industrial development, transfort, household as well as services sectors. Sriyana (2019) argued that the consumption of electric power and labor participation boosts the GDP growth in Indonesia for short as well as long term as these are the factors for growth in the country. Toman and Jemelkova (2003) are of the view that energy development is the central part for economic development. Energy development can boost the productivity of other factors of production that leads to sustainable economic development. World Energy Outlook (2004) affirms that energy is the need for the development of an economy. When economy grows, demand for more and better energy increases further.

The second group of researchers are those who considered foreign direct investment (FDI) has a positive role for any country in economic growth. Researchers concluded that the growth of capital formation is the must for economic growth (Omri and Kahouli, 2013). In developed economies, FDI is a factor behind high growth rate (Alfaro et al, 2010). As FDI has a positive role in economic growth and increases potential gain so have a positive spillover impact for the host country. On contrary, it is argued that economic growth is a motivating factor for attracting FDI, especially in developing economies (Hsiao and Shen, 2003). In addition, some studies argued that the direction of causal link between FDI and GDP is determined by country specific factors (Omri and kahouli, 2013; Zhang, 2001). Anwar and Nguyen (2010) indetified bidirectional causal association between FDI and GDP in Vietnam for the years 1996 to 2005. It means that FDI accelarates GDP growth and GDP growth also accelarates FDI in the study area. Similar results were found by Nguyen and Nguyen (2007).

The third group of researchers worked on the cointegration between FDI and energy use. Mielnik and Goldemberg (2000) identified direct association between FDI and consumption of energy in 20 developing countries. Sadorsky (2010) confirmed the same in a sample of 22 developing countries. Further, it is also argued that not only energy consumption contributes to FDI but FDI also can contribute to energy consumption like Bekhet and Othman (2011) identified a long run positive causal link between FDI and energy consumption during the years 1971 to 2009 in Malaysia. On contrary, Bento (2011) reported a modest inverse impact of FDI on consumption of energy in Purtagal during the years 1980 to 2007. Like many other countries of the world, Pakistan also required a lot of energy use for its socio and economic development. The present study is an attempt to analyze empirically the association of energy use, economic growth, FDI with degradation of environment in Pakistan.

The rest of the study is organized as follows. Section 2 deals with the previous literature. Section 3 represents the data and methodology. The study results are presented in section 4 while, the conclusions and recommendation are presented in section 5 .

\section{Literature Review}

\subsection{Energy Consumption and Economic Growth}

The association between aggregate output (GDP) and energy use is originated with the work of Kraft and Kraft (1978) since then, researchers both from developed and developing countries tried to investigate the energy association with GDP. Researchers like, Apergis and Payne (2010), Lyke (2015), Tang et al (2016) and Danmaraya and Hassan (2016a) found causal association running from 
energy consumption to GDP. A second group of researchers such as, Stern and Enflo (2013), Ouedraogo (2013) and Ahmed and Azam (2016) presented that aggregate output or GDP leads to energy consumption. A third group of researchers like, Rahman et al. (2015), and Solarin and Ozturk (2016) supported bidirectional causality between GDP and energy consumption. Whitch means a feedback relationship exist between the variables. A fourth group of researchers Oh and Lee (2004) and Alper and Oguz (2016) argued that energy consumption and aggregate output does not cause each other. This group is called the neutrality group.

For analyzing causal link between energy use and GDP, Danmaraya and Hassan (2016b) used the data of electricity consumption and manufacturing productivity of Nigeria. The study used Autoregressive Distributed Lag (ARDL) model and confirmed a causal link from electricity consumption (energy consumption) to manufacturing productivity. Odhiambo (2014), within a multivariate framework found causality from energy use to GDP in Kenya Republic and South Africa. The study was based on Sub Saharan African regions. Similarly, Tang et al (2016) studied the connection between energy usage and economic performance for Vietnam and found a causality from energy use towards economic performance. Rafindadi and Ozturk (2016) used data of Japanes economy and concluded feedback relationship in financial development, capital, exports, imports and other macroeconomic variables, used in the study while a twoway causality between economic growth and electricity usage. The study suggests the use of renewable energy consumption for Japanese economy. For the second group, Stern and Enflo (2013) used granger causality approach for Swedish economy and confirmed a one way causal association from GDP to energy use. Ouedraogo (2013) used panel data of 15 ECOWAS countries and analyzed the cointegration between energy consumption and economic performance. These results confirmed a unilateral causality between economic performance and energy use. Ahmed and Azam (2016) analyzed 119 countries and found causal link between output and energy use in 25 countries.

In third group, Ziramba (2009) used data of South Africa. The study used Toda-Yamamoto technique and confirmed feedback relationship between oil consumption and industrial output. Likewise, Rahman et al. (2015) for Malaysia, confirmed two way causal association between coal use and aggregate output. The study used Toda-Yamamoto causality test for analysis. Similarly, Solarin and Ozturk (2016) confirmed feedback hypothesis between natural gas use and economic performance in OPEC countries. In the neutrality group, Oh and Lee (2004), analyzed the association for aggregate output and energy use in Korea. They confirmed neutrality hypothesis, meaning that no causal association among the variables (GDP and energy consumption) were confirmed. Alper and Oguz (2016) supported Neutrality hypothesis in some European Countries (EU) that is Cyprus, Estonia, Hungry, Poland and Slovenia. Similarly, Solarin and Ozturk (2016) supported Neutrality hypothesis in Qatar and Angola. The study was based on OPEC countries.

\subsection{Energy Consumption and FDI}

Many empirical studies have been done for analyzing the association between FDI, energy use and environmental degradation. Some studies are supporting the pollution hevan hypothesis whereas others are in favor of pollution halo hypothesis. The first hypothesis (pollution hevan hypothesis) states that as developed countries following tough environmental standard so producing there is much costly as compared to developing countries where environmental standards are low. Because of this, the companies that are degrading environment prefer to shift their industrial units in developing countires where they do not face strick environmental regulations on one hand and policy makers and people of the developing countires also give lower value to a clean environment. 
On the other hand the pollution halo hypothesis states that inward FDI supports advancement of technology that promoted efficiency and high productivity in developing countries that is why it brings improvement in environment (Azam et al, 2019). Many studies are conduted on analyzing these like, Zeren (2015) empirically tested pollution haven and pollution halo hypothesis for USA, Canada, France and England for the period of 1970 to 2010. The results confirmed the existence of pollution halo hypothesis in USA, France and England, while the Pollution haven hypothesis is supported in Canada. Zhang (2011) analyzed data of China for the years 1980 to 2009 and concluded that FDI has positive impact on $\mathrm{CO}_{2}$ emissions. Ozturk and $\mathrm{Oz}$ (2016) used data of Turkey for the years 1974 to 2011 and confirmed the pollution halo hypothesis both in short as well as long period of time as the results confirmed that FDI had a direct significant association with environment. In addition, most of the studies analyzed a causal link between FDI inflows, energy use and emissions of $\mathrm{CO}_{2}$ such as, Kivyiro and Arminen (2014) analyzed the data of 6 countries of Sub- Saharan Africa for the years 1971 to 2009. They cheaked causality cheacked for FDI, energy use, GDP and $\mathrm{CO}_{2}$ emissions. The result suggests that FDI raises $\mathrm{CO}_{2}$ emissions in the countries. Peng et al. (2016) empirically analyzed the data of different provinces of China and identified a bi-directional causal association between FDI and GDP. In addition, Granger causality between GDP and emissions of $\mathrm{CO}_{2}$ was found in 15 provinces, whereas in Shanxi, bidirectional causality between $\mathrm{CO}_{2}$ emissions and GDP.The study also confirmed one way causal association between FDI and emissions of $\mathrm{CO}_{2}$ in Shanxi, Beijing, Guizhou and Henan whereas two way causality in Neimenggu were confirmed. Abdouli and Hammami (2017a)

Abdouli and Hammami (2017a) in their empirical study on 17 countries of Middle East and North Afria for the years 1990 to 2012 found that FDI inflows and capital stock contributed positively to growth of economy. Likewise, these results confirmed that in Middle East and North America (MENA) countries, economic growth reduces environmental degradation. Moreover, Abdouli and Hammami (2017b) found a two way causality between FDI and GDP, and energy consumption with GDP in the 17 countries for the span of 1990 to 2012.

\subsection{Energy Consumption and $\mathrm{CO}_{2}$ emissions}

$\mathrm{Liu}$ and Bae (2018) analyzed the association between emissions of $\mathrm{CO}_{2}$, energy use, per capita GDP and some other macroeconomic variables during the period of 1970 to 2015 . The results confirmed a positive and statistically significantassociation of energy use with emissions of $\mathrm{CO}_{2}$. The analysis was based on ARDL bound technique. Amri (2017) in Algeria, found a positive impact of non-renewable form of energy use on emissions of $\mathrm{CO}_{2}$ during 1980- 2011.

Gul et al. (2015) for Malaysia confirmed one-way causal association between energy use and $\mathrm{CO}_{2}$ emissions by bivariate as well as multivariate models in the period of 1975 to 2013 . Li et al. (2017) for China, analyzed the association between economic growth (GDP), emissions of $\mathrm{CO}_{2}$ and three types ( oil, gas and coal) of fossil energy use for the period of 1965 to 2015. The results indicated bidirectional causal link between GDP and gas consumption, GDP and coal consumption, and coal consumption and emissions of $\mathrm{CO}_{2}$, whereas unidirectional causal link was found from GDP to oil consumption and $\mathrm{CO}_{2}$ emissions. Lotfalipour et al. (2010) confirmed unidirectional causal association between GDP, energy use and emissions of $\mathrm{CO}_{2}$. In addition, Zhang and Cheng (20o9) for China, Ang (2007) for France, Apergis and Payne (2010) for ASEAN countries and Alshehry and Belloumi (2015) for Saudi Arabia confirmed unidirectional causal association between energy use and emissions of $\mathrm{CO}_{2}$. 


\section{Data and Empirical Method}

\subsection{Data Source and Variables Explanation}

The research study is based on time series data for the span of 1975 to 2018. Energy consumption (kg of oil equivalent per capita), GDP per capita annual growth, foreign direct investment (net inflow as percentage of GDP), carbon dioxide emission $\left(\mathrm{CO}_{2}\right.$ emissions(metric tons per capita) are the main variables. The other variables like exports, urbanization and, financial development are also included for which the data has obtained from World Bank Development Indicators (WDI). Three linear functions are developed for analyzing the determinants of FDI, economic growth and $\mathrm{CO}_{2}$ emissions. The first equation explain the association of energy consumption and FDI. The second equation is about the impact of energy use as well as of some other determinants on economic growth whereas the third equation explain the association of energy use, FDI inflows and, growth of economy with emission of $\mathrm{CO}_{2}$.

\subsection{Model Specifications}

The association between energy use with emissions of $\mathrm{CO}_{2}$ and some other macroeconomic variables has been analyzed by different econometric techniques by researchers. One interesting study of Azam et al. (2019) is done on China in which the association of energy use with $\mathrm{CO}_{2}$ and some other macroeconomic variables has been analyzed. The analytical techniques of their study are followed in this study. First for checking the stationarity characteristic of the time series data of the variables, Augmented Dickey and Fuller (1979) and Phillips and Perron (1988) tests are employed. Stationary of the variables at same level proposed the application cointegration test for identifying a long term relationship among the variables. For the purpose, Johansen's (1991, 1995 ) cointegration test is adopted. When the presence of cointegration is confirmed, canonical cointegrating regression (CCR) is has been used for the evaluation of the coefficients. Park (1992) argued that the method elimanate the biasedness of second order in OLS estimator, enhance the cointegrating regression as a result the cointegrating equation error term become a white noise, with mean value become zero while Variance become constant.

On the basis of the research work of Skanderson (1994), Braun (1994) and Azam et al. (2019), the model for the association of energy consumption and FDI adopted is given below.

\section{Model-I for FDI}

$$
F D I=\alpha_{0}+\alpha_{1} E C+\alpha_{2} E X+\alpha_{3} G D P+\alpha_{4} U R+\varepsilon_{1}
$$

where FDI represents foreign direct investment (net inflow as percentage of GDP), EC represents energy consumption (energy use $\mathrm{kg}$ of oil equivalent per capita), EX represents export (exports of goods and services as a percentage of GDP), GDP stands for (GDP per capita annual growth) that represents economic growth and, UR represents urbanization (total urban population as percentage of total population).

The direction expected for the slope coefficients are

$$
\alpha_{1}>0, \alpha_{2}>0, \alpha_{3}>0, \alpha_{4}>0
$$

\section{Model -II for Economic Growth}

$$
G D P=\alpha_{0}+\alpha_{1} C O_{2}+\alpha_{2} F D I+\alpha_{3} E C+\alpha_{4} U R+\varepsilon_{2}
$$


Where GDP stands for GDP per capita, $\mathrm{CO}_{2}$ represents carbon dioxide emissions, FDI stands for foreign direct investment, EC is energy use and, UR represents total urban population as percentage of total population.

The direction expected for the slope coefficients are

$$
\alpha_{1}<0, \alpha_{2}>0, \alpha_{3}>0, \alpha_{4}>0
$$

\section{Model-III for $\mathrm{CO}_{2}$ emissions}

$$
C O_{2}=\alpha_{0}+\alpha_{1} F D I+\alpha_{2} E C+\alpha_{3} G D P+\alpha_{4} U R+\alpha_{5} F D E+\varepsilon_{3}
$$

where $\mathrm{CO}_{2}$ stands for carbon dioxide emissions, FDI is foreign direct investment, EC is energy use, GDP is GDP per capita, UR is urbanization and FDE is financial development.

The direction expected for the slope coefficients are

$$
\alpha_{1}>0, \alpha_{2}>0, \alpha_{3}>0, \alpha_{4}>0, \quad \alpha_{5}>0
$$

\section{Empirical Results}

\subsection{Result of ADF and PP tests}

For this study, Augmented Dickey-Fuller (ADF) (1979) and Phillips and Perron (1988) tests have been adopted for identifying the stationarity nature of the variables. Augmented DickeyFuller test can be written in mathetical form as

$$
\Delta y_{t}=\emptyset y_{t-1}+\dot{x} \delta+\epsilon_{t}
$$

where $\emptyset=\rho-1-1 \leq \rho \leq 1$. The model is hypothesized as:

$$
\begin{aligned}
& H_{0}: \emptyset=0 \text { or } \rho=1 \\
& H_{1}: \emptyset<0 \text { or }-1 \leq \rho \leq 0
\end{aligned}
$$

The t-ratio of the $\emptyset$-coefficient of ADF test, where test statistic distribution is affected by serial correlation, has adjusted by Phillips-Perron (PP) test as:

$t_{\varnothing}^{\prime}=t_{\varnothing}\left(\frac{\gamma_{0}}{f_{0}}\right)^{1 / 2}-\frac{T\left(f_{0}-\gamma_{0}\right)(s e(\widehat{\emptyset}))}{2 f_{0}^{\frac{1}{2}} s}$

Where yo represents the evalution of error variance and $f_{\mathrm{o}}$ represents the zero occurrence of residual. Table 1 reveals the results of of ADF and PP tests. It shows that the variables that is, energy consumptiom, $\mathrm{CO}_{2}$ emissions, exports (EX) are non stationary at level at both trend, and with a trend and intercept. The variables are coverted into stationary by taking first difference in both ADF and PP tests. While GDP shows stationarity at level when both intercept and trend undertaken (by both ADF and PP tests). ADF test reveals that FDI is stationary at level but by PP test the said variable becomes stationary only at $1^{\text {st }}$ difference when both intercept and trnd are undertaken. Similarly another variable i.e urbanization is stationary at $1^{\text {st }}$ difference only by 
including intercept,whereas with the inclusion of trend the same variable becomes stationry only at second diferrence in ADF test but, the PP test confirms that urbanization is stationary at level when both intercept and trend are included. FDE is another variable of this research study which reveals stationarity at level when only intercept is included, but with the inclusion of trend the same variable not becomes stationary at level, but at first difference in both ADF and PP tests.

Table 1 Unit root test results

\begin{tabular}{|l|l|l|l|l|}
\hline & \multicolumn{2}{|c|}{ ADF Test Result } & \multicolumn{2}{c|}{ PP Test Result } \\
\hline variables & Intercept & Intercept \&Trend & Intercept2 & Intercept \&Trend2 \\
\hline EC & -2.01 & -0.042 & -1.894343 & -0.150071 \\
\hline & $-5.182^{* * *}$ & $-5.887^{* * *}$ & $-5.25^{* * *}$ & $-5.887^{* * *}$ \\
\hline GDP & $-4.608^{* * *}$ & $-4.642^{* * *}$ & $-4.648^{* * *}$ & $-4.601^{* * *}$ \\
\hline FDI & $-2.953^{* *}$ & $-3.247^{*}$ & -1.908708 & $-1.98633^{*}$ \\
\hline & & & $-4.376^{* * *}$ & $-4.337^{* * *}$ \\
\hline $\mathrm{CO}_{2}$ & -1.824492 & -0.248006 & -1.753753 & -0.377897 \\
\hline & $-6.602^{* * *}$ & $-7.379^{* *}$ & $-6.725^{* * *}$ & $-7.293^{* * *}$ \\
\hline EX & -1.024143 & -0.782212 & -1.024143 & -0.519416 \\
\hline & $-5.73^{* * *}$ & $-6.071^{* * *}$ & $-5.698^{* * *}$ & $-6.521^{* * *}$ \\
\hline $\mathrm{UR}$ & -1.521843 & -2.853552 & $-5.467^{* * *}$ & $-4.262^{* * *}$ \\
\hline & $-2.655^{*}$ & -2.574354 & & \\
\hline & & $-4.514^{* * *}$ & & \\
\hline FDE & $-2.813^{*}$ & -2.769475 & $-2.826^{*}$ & -2.839899 \\
\hline & & $-6.673^{* * *}$ & & $-7.247^{* * *}$ \\
\hline
\end{tabular}

${ }^{*}$ Significant at $1 \%,{ }^{* *}$ at $5 \%$, and *** at $10 \%$ level of significance.

\subsection{Cointegration Test Results}

For the identification of the existence of a long run association among variables, Johansen (1988) suggested likelihood ratio tests which can be presented in two seperate equations that is:

$$
\begin{aligned}
& J_{\text {max }}=-T \ln \left(1-\widehat{\lambda_{r+1}}\right) \\
& J_{\text {trace }}=-T \sum_{i=r+1}^{n} \ln \left(1-\widehat{\lambda}_{l}\right)
\end{aligned}
$$

Where $\lambda^{\wedge} \mathrm{i}$ is the $\mathrm{i}^{\text {th }}$ largest known association. The $T$ represents the size of the sample in the above two equations. Table 3 represents the results of cointegration test. It indicates, for all five variables, the null hypothesis of no association/cointegration is rejected meaning that longrun cointegration is confirmed in all variables. 
Table 2 Cointegration test result

\begin{tabular}{|c|c|c|c|c|}
\hline \multirow[t]{2}{*}{ Models } & \multirow[b]{2}{*}{ N. Hypothesis } & \multirow[b]{2}{*}{ A. Hypothesis } & \multicolumn{2}{|c|}{ Trace Test Statistics } \\
\hline & & & Statistics & $\begin{array}{l}\text { Critical } \\
\text { Value }\end{array}$ \\
\hline \multirow[t]{5}{*}{ I } & $\mathrm{r}=\mathrm{o}$ & $r=1$ & $144 \cdot 729 * *$ & 69.81889 \\
\hline & $r \leq 1$ & $r=2$ & $75 \cdot 527^{* *}$ & 47.85613 \\
\hline & $r \leq 2$ & $r=3$ & $33 \cdot 336^{* *}$ & 29.79707 \\
\hline & $r \leq 3$ & $r=4$ & $13.973^{* *}$ & $15 \cdot 49471$ \\
\hline & $r \leq 4$ & $r=5$ & $4.607^{* *}$ & 3.841466 \\
\hline \multirow[t]{5}{*}{ II } & $\mathrm{r}=\mathrm{o}$ & $r=1$ & $269.440^{* *}$ & 69.81889 \\
\hline & $r \leq 1$ & $r=2$ & $122.366^{* *}$ & 47.85613 \\
\hline & $r \leq 2$ & $r=3$ & $64.247^{* *}$ & 29.79707 \\
\hline & $r \leq 3$ & $r=4$ & $26.728^{* *}$ & $15 \cdot 49471$ \\
\hline & $r \leq 4$ & $r=5$ & 0.647 & 3.841466 \\
\hline \multirow[t]{5}{*}{ III } & $\mathrm{r}=\mathrm{o}$ & $r=1$ & $307.622^{* *}$ & $95 \cdot 75366$ \\
\hline & $r \leq 1$ & $r=2$ & $169 \cdot 799^{* *}$ & 69.81889 \\
\hline & $\mathrm{r} \leq 2$ & $r=3$ & $99.722^{* *}$ & 47.85613 \\
\hline & $r \leq 3$ & $r=4$ & $52.158^{* *}$ & 29.79707 \\
\hline & $r \leq 4$ & $r=5$ & $14 \cdot 511$ & $15 \cdot 49471$ \\
\hline
\end{tabular}

Levels of significance: ${ }^{* *} \mathrm{p}<0.05$

The results of cointegration test are given in table 2 which identified that that at 5 percent level of significance, the null hypothesis for no association between all the five variables is rejected in the I model. Similarly, For model II, the null hypothesis of no association is got rejected for four variables (out of five) at the $5 \%$ significance level. Likewise, The estimates of the model III also shows that the null hypothesis of no association for the four variables( out of six variables) are rejected at 5\% significance level.

\subsection{Canonical cointegrating Regression Result}

To estimate the coefficients of long-run equilibrium association, the present study applied the linear model with CCR technique. Long-run elasticity's results are given in Table 3. The CCR methodology is adopted to determine the long-run coefficients. Both an intercept and a deterministic trend were undertaken for appraisals of the coefficients. 
Table 3 Canonical cointegrating Regression Result

\begin{tabular}{|c|c|c|c|}
\hline Variables & $\begin{array}{l}\text { Model I } \\
\text { DV is FDI }\end{array}$ & $\begin{array}{l}\text { Model II } \\
\text { DV is GDP }\end{array}$ & $\begin{array}{l}\text { Model III } \\
\mathrm{DV} \text { is } \mathrm{CO}_{2} \text { emissions }\end{array}$ \\
\hline $\mathrm{C}$ & $\begin{array}{l}7.494 \\
(1.351) \\
\end{array}$ & $\begin{array}{l}-6.626 \\
(0.606)\end{array}$ & $\begin{array}{l}-0.829 \\
(0.058)\end{array}$ \\
\hline $\mathrm{EC}$ & $\begin{array}{l}0.046^{*} \\
(0.000)\end{array}$ & $\begin{array}{l}0.060 * * \\
(0.039)\end{array}$ & $\begin{array}{l}0.002^{*} \\
(0.000)\end{array}$ \\
\hline GDP & $\begin{array}{l}0.084^{* * *} \\
(0.094)\end{array}$ & & $\begin{array}{l}-0.001 \\
(0.707)\end{array}$ \\
\hline FDI & & $\begin{array}{l}1.294^{*} \\
(0.007)\end{array}$ & $\begin{array}{l}0.016 * * \\
(0.047)\end{array}$ \\
\hline EX & $\begin{array}{l}-0.228 * \\
(0.000)\end{array}$ & & \\
\hline $\mathrm{CO}_{2}$ emissions & & $\begin{array}{l}-2.844 \\
(0.845) \\
\end{array}$ & \\
\hline $\begin{array}{l}\text { UR } \\
\text { FDE }\end{array}$ & $\begin{array}{l}-0.715^{\star} \\
(0.000)\end{array}$ & $\begin{array}{l}1.077^{* *} \\
(0.021)\end{array}$ & $\begin{array}{l}0.023^{*} \\
(0.001) \\
-0.003^{*} \\
(0.005)\end{array}$ \\
\hline $\mathrm{R}^{2}$ & 0.721 & 0.849 & 0.991 \\
\hline
\end{tabular}

DV: dependent variable

${ }^{*}$ Significant at $1 \%,{ }^{* *}$ at $5 \%$, and ${ }^{* * *}$ at $10 \%$ level of significance.

The results of model I shows that all the mentioned variables of the stated model i.e, energy consumption, GDP, export, and urbanization are significantly cointegrated with FDI, Where energy consumption shows positive and the other two variables i.e, export and urbanization are negatively associated with FDI.

The results for model I reveal that 1 percent rise in energy use increases FDI by 0.05 percent. Furthermore 1 percent increase in exports and urbanization decreases FDI by 0.23 and 0.72 respectively. Empirical findings of Omri and Kahouli (2014), and Azam et al. (2019) shows the same si association between the variables.

Model II checked the association between energy consumption, FDI, $\mathrm{CO}_{2}$ emissions, urbanization and GDP. The result shows that except $\mathrm{CO}_{2}$ emissions, all the stated variables of model II namely energy consumption, FDI, and urbanization are significantly associated with economic growth. It has been confirmed that the association of energy consumption and urbanization with GDP is positive at $5 \%$ significance level whereas the significant assocaition of FDI with GDP at $1 \%$ significance level. Furthermor the results confirm that $\mathrm{CO}_{2}$ emissions are adversely associated with economic growth but the result is insignificant meaning that no association between $\mathrm{CO}_{2}$ emissions and GDP is found.

The CCR long-run estimates reveal that a 1percent increase in energy consumption, FDI, and urbanization increases GDP by $0.60 \%, 1.294 \%$ and $1.077 \%$ respectively. These results are in line 
with Jalil and Mahmud (2009) for China, Jebli and Youssef (2015), and Jebli et al. (2015) for Tunisia and, Azam et al. (2019) in case of Pakistan.

The estimates of Model III show that energy consumption, FDI and urbanization have significant and direct association with $\mathrm{CO}_{2}$ emissions, whereas financial development has significant and negative association with $\mathrm{CO}_{2}$ emissions. The results of model III indicate that 1percent increase in energy consumption, FDI, and urbanization raises $\mathrm{CO}_{2}$ emmissions by $0.002 \%, 0.016 \%$ and $0.023 \%$, respectively, while percent increase in financial development decreases $\mathrm{CO}_{2}$ emission by $0.013 \%$. Moreover, the results show that GDP and $\mathrm{CO}_{2}$ emissions are not associated.These results are just like the results of Ang (2007), Apergis and Payne, (2009), and Azam et al. (2019).

\section{Concluding Remarks}

The importance of energy use in the growth process for a country cannot be denied. Energy is just like the life blood in an economy. So, the primary aim of the research work was to know about the association of energy consumpotion with degradation of environment resulted from the emissions of $\mathrm{CO}_{2}$, economic growth measured by GDP per capita annual growth rate, and FDI (foreign direct investment inflows) in case of Pakistan for the period of 1975 to 2018. For avoiding any misspecification in the regression models, the other determinants that is, exports, financial development and urbanization are also included in the study. The unit root characteristic of the data is checked by ADF and PP test, after that, CCR method for the estimation of the unknown parameters for all the three models have been applied. The empirical results obtained are statistically significant and aline with theory and the past empirical studies mentioned above.

The CCR technique is adopted to estimate the coefficient of the long run association amongst the variables. The estimates of model I show that energy use and GDP are positively cointegrated with FDI inflows while exports and urbanization are negatively linked with the FDI inflows. All the results are also statistically signifianct. The results reveals that any increase in energy use and GDP growth increases FDI inflows whereas an increase in exports and urbanization results in a reduction in FDI inflows. The estimates of model 2 show that energy consumption, FDI inflows and urbanization have significant positive while $\mathrm{CO}_{2}$ emissions has negative association with economic growth. These results reveal that an increase in energy consumption, FDI inflows, and urbanization leads to increase GDP whereas a rise in $\mathrm{CO}_{2}$ emissions reduces GDP.

Likewise, The results of model III reveals that energy consumption, FDI inflows and urbanization have direct and significant while, economic growth has an inverse and insignificant association with emissions of $\mathrm{CO}_{2}$. Similarly, the impact of financial development on $\mathrm{CO}_{2}$ emissions are also inverse but significant. It suggests that a increase rise energy use, FDI inflows, and urbanization increases $\mathrm{CO}_{2}$ emissions while, an improvement in financial development reduces $\mathrm{CO}_{2}$ emissions.

The above results recommend that policy makers need to make effective policies for sustainable economic growth along with efficient energy use. It is also suggested that for sustainable economic growth, government need to make effective policies for promoting FDI and planned urbanization in order to control the negative impact of these factors ( urbanization, FDI and GDP) on environment. 


\section{References}

Abdouli, M, \& Hammami, S. (2017a). The impact of FDI inflows and environmental quality on economic growth: an empirical study for the MENA countries. Journal of the Knowledge Economy 8(1): pp. 254-278.

Abdouli, M., \& Hammami, S. (2017b). Exploring links between FDI inflows, energy consumption, and economic growth: further evidence from MENA countries. Journal of Economic Development, 42(1): pp. 95-117.

Ahmed, M., \& Azam, M. (2016). Causal nexus between energy consumption and economic growth for high, middle and low income countries using frequency domain analysis. Renewable and Sustainable Energy Reviews, 6o: pp. 653-678.

Alfaro, L., Chanda, A., Ozcan, K. S., \& Sayek, S. (2010). Does foreign direct investment promote growth? Exploring the role of financial markets on linkages. Journal of Development Economics 912: pp.242-256.

Alper, A., \& Oguz, O. (2016). The role of renewable energy consumption in economic growth: Evidence from asymmetric causality. Renewable and Sustainable Energy Reviews, 6o: pp.953959.

Alshehry, A. S., \& Belloumi, M. (2015). Energy consumption, carbon dioxide emissions and economic growth: The case of Saudi Arabia. Renewable and Sustainable Energy Reviews, 41: pp. 237247.

Amri, F. (2017). Carbon dioxide emissions, output, and energy consumption categories in Algeria. Environmental Science and Pollution Research, 24(17): pp.14567- 14578.

Anwar, S., \& Nguyen, L. P. (2010). Foreign direct investment and economic growth in Vietnam. Asia Pacific Business Review, 16. Pp. 83-202.

Ang, J, B. (2007). CO2 emissions, energy consumption, and output in France. Journal of Energy Policy, 35: pp. 4772-4778.

Apergis, N., \& Payne, J. (2009). CO2 emissions, energy usage and output in Central America. Energy Policy 37: pp.3282-3286.

Apergis, N., \& Payne, J. E. (2010). Energy consumption and growth in South America: Evidence from a panel error correction model. Energy Economics, 32(6): pp.1421-1426.

Azam, M., Khan, A. Q., \& Ozturk, I. (2019). The effects of energy on investment, human health, environment and economic growth: empirical evidence from China. Environmental Science and Pollution Research (2019) 26: pp.10816-10825.

Bekhet, H.A., \& Othman, N.S. (2011). Causality Analysis among Electricity Consumption, Consumer Expenditure, GDP and Foreign Direct Investment FDI: Case Study of Malaysia. Journal of Economics and International Finance, 3: pp. 228-235.

Bento, J.P. (2011). Energy savings via foreign direct investment?- Empirical evidence from Portugal. WorkinPaper No. 2011/24, Maastricht School of Management.

Braun, R. A. (1994). How large is the optimal inflation tax? Journal of Monetary Economics, 34: pp. 201-214.

Danmaraya, I. A., \& Hassan, S. (2016a). Electricity consumption and manufacturing sector productivity in Nigeria: An ARDL-bounds testing approach. International Journal of Energy Economics and Policy, 6(2): pp. 1-7.

Danmaraya, I. A., \& Hassan, S. (2016b). Energy consumption and manufacturing performance: Evidence from panel data for low-income Sub-Sahara African countries. International Energy Journal, 16(2): pp.57-64. 
Dickey, D., \& Fuller, W. (1979). Distribution of the estimators for autoregressive time series with a unit root. Journal of the American Statistical Association, 74: pp. 427-431.

Gul, S., Zou, X., Hassan, C. H., Azam, M., \& Zaman, K. (2015). Causal nexux between energy consumption and carbon dioxide emission for Malaysia using maximum entropy bootstrap approach. Environmental Science and Pollution Research 22(24): pp. 19773-19785.

Hsiao, C., \& Shen, Y. (2003). Foreign direct investment and economic growth: the importance of institutions and urbanization. Economic Growth and Cultural Change 51: pp. 883-896.

Jalil A, Mahmud, S. F. (2009). Environment Kuznets curve for CO2 emissions: a cointegration analysis for China. Energy Policy 37: pp. 5167-5172.

Jebli, M. B., Youssef, S. B., \& Apergis, N. (2015). The dynamic interaction between combustible renewables and waste consumption and international tourism: the case of Tunisia. Environmental Science \& Pollution Research, 22: pp.12050-12061.

Jebli, M. B., \& Youssef, S. B. (2015). The environmental Kuznets curve, economic growth, renewable and non-renewable energy, and trade in Tunisia. Renewable \& Sustainable Energy Reviews, 47: pp.173-185.

Johansen, S. (1991). Estimation and hypothesis testing of cointegration vectors in Gaussian vector autoregressive models. Econometrica 59: pp. 1551-1580.

Johansen, S. (1995). Likelihood-based inference in cointegrated vector autoregressive models. Oxford University Press, New York.

Kivyiro, P., \& Arminen, H. (2014). Carbon dioxide emissions, energy consumption, economic growth, and foreign direct investment: Causality analysis for Sub-Saharan Africa. Energy, 74: pp. 595606.

Kraft, J., \& Kraft, A. (1978). Relationship between energy and GNP. Journal of Energy Development, 3(2): pp. 401-403.

Li, H., Li, B., \& Lu, H. (2017). Carbon dioxide emissions, economic growth, and selected types of fossil energy consumption in China: empirical evidence from 1965 to 2015. Sustainability 9 (697): pp.1-14

Liu, X., \& Bae, J. (2018). Urbanization and industrialization impact of $\mathrm{CO}_{2}$ emissions in China. Journal of Cleaner Production, 172 : pp.178-186.

Lotfalipour, M. R., Falahi, M. A., \& Ashena, M. (2010). Economic growth, CO2 emissions, and fossil fuels consumption in Iran Energy, 35: pp.5115-5120.

Iyke, B. N. (2015). Electricity consumption and economic growth in Nigeria: A revisit of the energygrowth debate. Energy Economics, 51: pp.166-176.

Mielnik, O., \& Goldemberg, J. (2000). Converging to a common pattern of energy use in developing and industrialized countries', Energy Policy, 28: pp. 503-508.

Nguyen, A.N., \& Nguyen, T. (2007). Foreign direct investment in Vietnam: an overview and analysis of the determination of spatial distribution, Development and polices research center, Working Paper, Hanoi, Vietnam.

Odhiambo, N. M. (2014). Energy dependence in developing countries: Does the level of income matter? Atlantic Economic Journal, 42(1): pp. 65-77.

Oh, W., \& Lee, K. (2004). Energy consumption and economic growth in Korea: Testing the causality relation. Journal of Policy Modeling, 26(8): pp. 973-981.

Omri, A., \& Kahouli, B. (2014). Causal relationships between energy consumption, foreign direct investment and economic growth: fresh evidence from dynamic simultaneous-equations models. Energy Policy 67: pp. 913-922.

Omri, A. and Kahouli, B. (2013). The nexus between foreign investment, domestic capital and economic growth:Empirical evidence from the MENA region. Research in Economics, DOI 
http://dx.doi.org/10.1016/j.rie.2013.11.001.

Ouedraogo, N. S. (2013). Energy consumption and economic growth: Evidence from the economic community of West African States (ECOWAS). Energy Economics, 36: pp. 637-647.

Ozturk, Z., \& Oz, D. (2016). The relationship between energy consumption, income, foreign direct investment, and $\mathrm{CO} 2$ emissions: the case of Turkey. Journal of Faculty of Econmics and Administrative Science 6(2): pp. 69-288.

Park, J. Y. (1992). Canonical cointegrating regressions. Econometrica 6o(1): pp.119-143.

Peng, H., Tan, X., Li, Y., \& Hu, L. (2016). Economic growth, foreign direct investment and CO2 emissions in China: a panel granger causality analysis. Sustainability 8(233): pp. 1-13.

Phillips, P. C. B., \& Perron, P. (1988). Testing for a unit root in time series regression. Biometrika 75(2): pp. 335-346.

Rafindadi, A. A., \& Ozturk, I. (2016). Effects of financial development, economic growth and trade on electricity consumption: Evidence from Post-Fukushima Japan. Renewable and Sustainable Energy Reviews, 54: pp.1073-1084.

Rahman, M. S., Junsheng, H., Shahari, F., Aslam, M., Masud, M.M., Banna, H., \& Liya, M. (2015). Long-run relationship between sectoral productivity and energy consumption in Malaysia: An aggregated and disaggregated viewpoint. Energy, 86: pp. 436-445.

Rapu, C, S., Adenuga, A. O., Kanya, W. J., Abeng, M. O., Golit, P. D. , Hilili, M. J., Uba, I. A., \& Ochu, E. R. (2015). Analysis of Energy Market Conditions in Nigeria Occasional Paper No. 55 Central Bank of Nigeria.

Sadorsky, P. (2010). The impact of financial development on energy consumption in emerging economies. Energy Policy, 38: pp. 2528-2535.

Skanderson, D. M. (1994). Evidence on the fisher equation: the long run and the short run, PhD Dissertation. University of Rochester, Rochester, New York.

Solarin, S.A., \& Ozturk, I. (2016). The relationship between natural gas consumption and economic growth in OPEC members. Renewable and Sustainable Energy Reviews, 58: pp. 1348-1356.

Sriyana, J. (2019). Dynamic Effects of Energy Consumption on Economic Growth in an Emerging Economy. International Journal of Energy Economics and Policy, Econ journals, 9(4): pp.283290.

Stern, D. I., \& Enflo, K. (2013). Causality between energy and output in the long-run. Energy Economics, 39: pp.135-146.

Tang, C. F., Tan, B. W., \& Ozturk, I. (2016). Energy consumption and economic growth in Vietnam. Renewable and Sustainable Energy Reviews, 54: pp. 1506-1514.

Toman, M., \& Jemelkova, B. (2003). Energy and economic development: an assessment of the state of knowledge. Discussion paper: pp. 03-13.

World Energy Outlook (2004). Chapter 10, energy and development. IEA Publications, Paris: pp. 329-365.

Zeren, F. (2015). The impact of foreign direct investment on $\mathrm{CO} 2$ emission: pollution halo or pollution haven hypothesis? Journal of Yasar University, 10(37): pp. 6442-6448.

Zhang, K. H., (2001). Does Foreign Direct Investment Promote Economic growth? Evidence from East Asia and Latin America. Contemporary Economic Policy, 19: pp. 175-185.

Zhang, X. P., \& Cheng, X. M. (2009). Energy consumption, carbon emissions and economic growth in China. Ecological Economics, 68: pp. 2706-2712.

Zhang, Y. J. (2011). The impact of financial growth on carbon emissions: an empirical analysis in China. Energy Policy 39: pp. 2197-2203.

Ziramba, E. (2009). Disaggregate energy consumption and industrial production in South Africa. Energy Policy, 37(6): pp. 2214-2220. 